\title{
Effects of Phosphorous and Phosphoric Acids on Growth and Phosphorus Concentrations in Container-grown Tropical Ornamental Plants
}

\author{
Timothy K. Broschat
}

AdDitional INDEX wORDs. metalaxyl, phosphorous acid, phosphonic acid, phosphonate, phosphate, phosphite, Hibiscus rosa-sinensis, Jasminum multiflorum, Pseuderanthemum laxiflorum, Dypsis lutescens, Spatbiphyllum

Summary. Chinese hibiscus (Hibiscus rosa-chinensis), shooting star (Pseuderanthemum laxiflorum), downy jasmine (Jasminum multiflorum), areca palm (Dypsis lutescens), and 'Jetty' spathiphyllum (Spathiphyllum) were grown in containers using Osmocote Plus 15-9-12 (15N-3.9P-10K), which provided phosphorus (two experiments), or resin-coated urea plus sulfur-coated potassium sulfate, which provided no phosphorus (one experiment). Plants were treated with water drenches (controls), drenches with metalaxyl fungicide only, drenches with phosphoric acid $\left(\mathrm{PO}_{4}-\mathrm{P}\right)$, drenches with metalaxyl plus phosphorus from phosphoric acid, drenches with PhytoFos 4-28-10 [4N-12.2P-8.3K, a fertilizer containing phosphorous acid $\left(\mathrm{PO}_{3}-\mathrm{P}\right)$, a known fungicidal compound], or a foliar spray with PhytoFos 4-28-10. Plants receiving soil drenches with equivalent amounts of $P$ from PhytoFos 4-28-10, $\mathrm{PO}_{4}-\mathrm{P}$, or $\mathrm{PO}_{4}-\mathrm{P}+$ metalaxyl generally had the greatest shoot and root dry weights and foliar $\mathrm{PO}_{4}-\mathrm{P}$ concentrations. There were no differences between the control and metalaxyl-treated plants, indicating that root rot diseases were not a factor. Therefore, responses from PhytoFos 4-28-10 were believed to be due to its nutrient content, rather than its fungicidal properties. Foliar-applied PhytoFos 4-29-10 produced plants that were generally similar in size to control plants or those receiving metalaxyl only drenches. Fertilizers containing $\mathrm{PO}_{3}-\mathrm{P}$ appear to be about as effective as $\mathrm{PO}_{4}-\mathrm{P}$ sources when applied to the soil, but are relatively ineffective as a $P$ source when applied as a foliar spray. A distinct positive synergistic response for shoot and root dry weights and foliar $\mathrm{PO}_{4}-\mathrm{P}$ concentrations was observed for the $\mathrm{PO}_{4}-\mathrm{P}+$ metalaxyl treatment when no $P$ was applied except as a treatment.

$\mathrm{O}$ rthophosphate $\left(\mathrm{PO}_{4}-\mathrm{P}\right)$ is generally recognized as the only form of $\mathrm{P}$ that can be directly utilized by higher plants (Mengel and Kirkby, 1979). However, in recent years phosphorous acid (=phosphonic acid) and its salts, phosphites, or phosphonates, collectively referred to in this paper as $\mathrm{PO}_{3}-\mathrm{P}$, have been widely promoted as an alternative $\mathrm{P}$ fertilizer source. $\mathrm{PO}_{3}-\mathrm{P}$ must be oxidized within the soil to $\mathrm{PO}_{4}-\mathrm{P}$ before it can be taken up and utilized by plants, a microbially-mediated process that can take months or longer (Adams and Conrad, 1953; MacIntire et al., 1950; Malacin-

University of Florida, Department of Environmental Horticulture, Ft. Lauderdale Research and Education Center, 3205 College Ave., Ft. Lauderdale, FL 33314.

This research was supported by the Florida Agricultural Experiment Station and was approved for publication as Journal Series No. R-11023. The author wishes to thank Anita Durden and Susan Thor for their assistance in this study. ski and Konetzka, 1966). $\mathrm{PO}_{3}-\mathrm{P}$ has long been known to be an effective phloem-translocated fungicide against fungi such as Pythium and Phytophthora (Guest and Grant, 1991), but its value as a $P$ fertilizer has been the subject of considerable debate (McDonald et al., 2001; Rickard, 2000).

More rapid growth and yield responses to foliar-applied $\mathrm{PO}_{3}-\mathrm{P}$ have been attributed to improved $P$ nutrition in 13 species of agronomic, vegetable, and tree fruit crops (Rickard, 2000), but improperly designed experiments have made it difficult to separate out the effects of $P$ nutrition from the wellknown fungicidal properties of $\mathrm{PO}_{3}-\mathrm{P}$. For example, $\mathrm{PO}_{3}-\mathrm{P}$ was not compared to equivalent rates of $\mathrm{PO}_{4}-\mathrm{P}$, or no fungicide equivalent in activity to $\mathrm{PO}_{3}$ $\mathrm{P}$ was included to eliminate possible fungicide effects. Furthermore, these "fertilizer" formulations of $\mathrm{PO}_{3}-\mathrm{P}$ are recommended primarily for application as a foliar spray to plants already receiving typical $\mathrm{P}$ fertilization from $\mathrm{PO}_{4}-\mathrm{P}$ sources. This would suggest that many of the observed responses to $\mathrm{PO}_{3}-\mathrm{P}$ may in fact be due to a suppression of root rotting fungi that may be affecting growth or yield of a particular crop. Such products may be marketed as fertilizers rather than as pesticides in order to avoid costly toxicological and efficacy studies. The purpose of this study was to compare the growth and $\mathrm{P}$ uptake responses in a variety of container-grown tropical ornamental plants treated with a commercially available "fertilizer" containing $\mathrm{PO}_{3}$ $\mathrm{P}, \mathrm{PO}_{4}-\mathrm{P}$, or a fungicide with similar activity to $\mathrm{PO}_{3}-\mathrm{P}$.

\section{Materials and methods}

Liners of chinese hibiscus, shooting star, downy jasmine, areca palm, and 'Jetty' spathiphyllum were transplanted into 2.5 -L plastic containers using a 5 pine bark: 4 sedge peat: 1 sand potting substrate amended with 12 $\mathrm{lb} /$ yard $^{3}$ of dolomite and $1.5 \mathrm{lb} /$ yard $^{3}$ of Micromax (Scotts Co., Marysville, Ohio) on 15 Apr. 2002. All pots were top-dressed with $21 \mathrm{~g}$ of Osmocote Plus 15-9-12 (8 to 9 month at $\left.70^{\circ} \mathrm{F}\right)$ at the time of planting. Ten replicate pots of each species were given the following treatments: l) $150 \mathrm{~mL}$ of deionized water applied as a soil drench every 3 weeks (control), 2) $150 \mathrm{~mL}$ of a $0.157 \mathrm{~mL} \cdot \mathrm{L}^{-1}(2 \mathrm{fl} \mathrm{oz} / 100 \mathrm{gal})$ metalaxyl solution (Subdue Maxx; Syngenta, Greensboro, N.C.) applied as a soil drench every 6 weeks, 3 ) a

\begin{tabular}{llll}
\hline $\begin{array}{l}\text { Units } \\
\text { To convert U.S. to SI, } \\
\text { multiply by }\end{array}$ & U.S. unit & SI unit & $\begin{array}{l}\text { To convert SI to U.S., } \\
\text { multiply by }\end{array}$ \\
\hline 29.5735 & $\mathrm{fl} \mathrm{oz}$ & $\mathrm{mL}$ & 0.0338 \\
0.0781 & $\mathrm{fl} \mathrm{oz} / 100 \mathrm{gal}$ & $\mathrm{mL} \cdot \mathrm{L}^{-1}$ & 12.8000 \\
3.7854 & gal & $\mathrm{L}$ & 0.2642 \\
2.5400 & inch $(\mathrm{es})$ & $\mathrm{cm}$ & 0.3937 \\
0.5933 & $\mathrm{lb} / \mathrm{yard}^{3}$ & $\mathrm{~kg} \cdot \mathrm{m}^{-3}$ & 1.6856 \\
28.3495 & $\mathrm{oz}$ & $\mathrm{g}$ & 0.0353 \\
28,350 & $\mathrm{Oz}$ & $\mathrm{mg}$ & $3.5274 \times 10^{-5}$ \\
$\left({ }^{\circ} \mathrm{F}-32\right) \div 1.8$ & ${ }^{\circ} \mathrm{F}$ & ${ }^{\circ} \mathrm{C}$ & $\left(1.8 \times{ }^{\circ} \mathrm{C}\right)+32$
\end{tabular}


soil drench of phosphoric acid (Fisher Scientific, Fair Lawn, N.J.) (150 mL of a $0.01 \mathrm{M} \mathrm{P}$ solution) applied every 3 weeks, 4) $150 \mathrm{~mL}$ of a $0.157 \mathrm{~mL} \cdot \mathrm{L}^{-1}$ metalaxyl solution applied as a soil drench every 6 weeks plus a soil drench of $\mathrm{P}$ from phosphoric acid $(150 \mathrm{~mL}$ of a $0.01 \mathrm{M}$ P solution) every 3 months, 5 ) a foliar spray applied to the point of run-off containing PhytoFos 4-28-10 (Organic Laboratories, Stuart, Fla.), a product containing phosphorous acid, urea, and potassium hydroxide diluted $1: 100$ with water $(=0.02 \mathrm{M} \mathrm{P})$ applied every 3 weeks, and 6) PhytoFos 4-28-10 applied as a soil drench (150 mL of a $0.01 \mathrm{M} \mathrm{P}$ solution) every 3 weeks. Application rates and frequencies for PhytoFos 4-28-10 and metalaxyl were label rates, and $\mathrm{PO}_{4}-\mathrm{P}$ soil drench application rates provided equivalent amounts of $\mathrm{P}$ ( $47 \mathrm{mg} / \mathrm{pot})$ to that applied by soil drenches of PhytoFos 4-28-10.

Plants were grown under 55\% shadecloth and received $\sim 2 \mathrm{~cm}$ of water daily from overhead irrigation plus natural rainfall $(\sim 150 \mathrm{~cm} /$ year $)$. When most plants for a species reached marketable size for their container (4 months for hibiscus, shooting star, and downy jasmine and 7 months for spathiphyllum and areca palm), leaf samples consisting of the youngest fully expanded leaves (central leaflets of this leaf for areca palm) were collected for foliar analysis. Dried leaf material was ground and digested using the sulfuric acid-hydrogen peroxide method (Hach et al., 1987). Phosphate-P determinations were made using the ascorbic acid method (Kuo, 1996). The plant shoots were then cut off at the soil line and dried at $60{ }^{\circ} \mathrm{C}$ for dry weight determination. Roots were washed free of potting soil and were similarly dried for dry weight determination. Data were analyzed by analysis of variance with mean separation by the Waller-Duncan k-ratio method (SAS Institute, Cary, N.C.).

A second experiment of similar design, except that spathiphyllums were not included, was established on 7 Nov. 2002. A third experiment utilizing all of the plant species included in Expt. 1 was set up on $23 \mathrm{Feb}$. 2004. It differed from the first two experiments in that no $\mathrm{P}$ was applied to the pots except for that included in the treatments. Nitrogen was provided by 4.9 $\mathrm{g} /$ pot of resin-coated urea (Scotts Co.) every 3 months and $\mathrm{K}$ was provided by $3.2 \mathrm{~g} /$ pot of sulfur-coated potassium sulfate (Pursell Industries, Sylacauga, Ala.) every 3 months.

\section{Results}

All treatments produced plants with excellent color, with no visibly detectable differences in color for any species in any experiment (data not shown). When chinese hibiscus were grown with Osmocote Plus 15-9-12, which provided sufficient $\mathrm{P}$ for normal growth (Expts. 1 and 2), plant responses to additional $\mathrm{P}$ from either $\mathrm{PO}_{4}-\mathrm{P}$ or $\mathrm{PO}_{3}-\mathrm{P}$ sources were limited (Table 1). Only shoot dry weight in Expt. 1 showed significant differences among treatments. In this case, soil drenches with $\mathrm{PO}_{4}-\mathrm{P}$ alone resulted in greater shoot dry weight than the foliar spray with PhytoFos 4-28-10 or water-drenched control plants. Although there were no differences in leaf $\mathrm{PO}_{4}-\mathrm{P}$ concentrations among treatments in Expt. 1, in Expt. 2 leaf $\mathrm{PO}_{4}-\mathrm{P}$ concentrations were enhanced by the addition of metalaxyl to the $\mathrm{PO}_{4}-\mathrm{P}$ drench.

When hibiscus were grown without any $\mathrm{P}$ source than that provided by the experimental treatments (Expt. 3 ), shoot and root dry weights were greater for plants treated with $\mathrm{PO}_{4}-$ $\mathrm{P}+$ metalaxyl drenches, PhytoFos 428-10 drenches, and $\mathrm{PO}_{4}-\mathrm{P}$ drenches than for those receiving a metalaxyl drench only, foliar-applied PhytoFos 4-28-10, or water only (Table 1). Root dry weights were greater for plants receiving $\mathrm{PO}_{4}-\mathrm{P}$ drenches alone than for those receiving a metalaxyl drench or a PhytoFos 4-28-10 foliar spray. Foliar $\mathrm{PO}_{4}-\mathrm{P}$ concentrations were highest for the plants receiving the $\mathrm{PO}_{4}-\mathrm{P}+$ metalaxyl drench, suggesting again that metalaxyl enhanced the uptake of $\mathrm{P}$ from $\mathrm{PO}_{4}-\mathrm{P}$.

Shooting star grown with Osmocote Plus 15-9-12 had no differences in root dry weight in both Expts. 1 and 2, and only in Expt. 2 were shoot dry weight differences significant (Table 1). When no P source other than the treatments were provided (Expt. 3), plants receiving PhytoFos 4-28-10 drenches had significantly greater shoot and root dry weights than plants receiving metalaxyl only, PhytoFos 4-28-10 sprays, or water only. Foliar $\mathrm{PO}_{4}-\mathrm{P}$ concentrations were highest for plants receiving drenches with $\mathrm{PO}_{4}-\mathrm{P}+$ metalaxyl or $\mathrm{PO}_{4}-\mathrm{P}$ alone in Expt. 3.

There were no differences in shoot or root dry weights for downy jasmine grown with Osmocote Plus 15-9-12 in Expt. 2, but $\mathrm{PO}_{4}-\mathrm{P}$ drenches resulted in greater shoot and root dry weights than plants receiving water, PhytoFos 4-28-10, or $\mathrm{PO}_{4}-\mathrm{P}+$ metalaxyl drenches in Expt. 1 (Table 1). When grown with no other $P$ sources than the treatments (Expt. 3), downy jasmine in all treatments had similar shoot and root dry weights. Foliar $\mathrm{PO}_{4}-\mathrm{P}$ concentrations of all treatments were similar when grown with Osmocote Plus 15-9-12 in Expt. 1, but were significantly higher for plants treated with drenches of $\mathrm{PO}_{4}-\mathrm{P}$ alone, PhytoFos 4-28-10, or $\mathrm{PO}_{4}^{4}-\mathrm{P}+$ metalaxyl in Expt. 2. When downy jasmine were grown with no other $\mathrm{P}$ source than the experimental treatments, foliar $\mathrm{PO}_{4}-\mathrm{P}$ concentrations were greatest for plants receiving drenches of $\mathrm{PO}_{4}-\mathrm{P}$ alone, $\mathrm{PO}_{4}-\mathrm{P}+$ metalaxyl, or PhytoFos 4-28-10.

When grown with Osmocote Plus 15-9-12 (Expt. 1), spathiphyllums had no significant differences among treatments in shoot or root dry weight or foliar $\mathrm{PO}_{4}-\mathrm{P}$ concentrations (Table 1). However, when grown with no $P$ except for that provided by the treatments, plants grown with drenches of $\mathrm{PO}_{4}-\mathrm{P}$ or PhytoFos 4-28-10, or $\mathrm{PO}_{4}^{-}$ $\mathrm{P}+$ metalaxyl had significantly greater shoot and root dry weights than those receiving other treatments. Plants receiving $\mathrm{PO}_{4}-\mathrm{P}+$ metalaxyl drenches also had greater shoot dry weights than plants receiving water or metalaxyl drenches or PhytoFos 4-28-10 foliar sprays. Spathiphyllums receiving drenches with $\mathrm{PO}_{4}-\mathrm{P}+$ Metalaxyl had higher foliar $\mathrm{PO}_{4}^{-}-\mathrm{P}$ concentrations than all other treatments as occurred in hibiscus and shooting star.

Areca palm grown either with or without Osmocote Plus 15-9-12 as a $P$ source generally did not show significant differences in shoot or root dry weights in Expt. 2, but in Expt. 1 areca palm grown with $\mathrm{PO}_{4}-\mathrm{P}$ drenches had greater shoot and root weights than water-drenched control plants or those receiving PhytoFos 4-28-10 foliar sprays (Table 1). Foliar $\mathrm{PO}_{4}-\mathrm{P}$ concentrations did not differ among treatments when provided with P from Osmocote Plus 15-9-12 in either Expt.1 or 2, but when no P 
Table 1. Effects of phosphoric acid $\left(\mathrm{PO}_{4}-\mathrm{P}\right)$, phosphorous acid ( $\left.\mathrm{PO}_{3}-\mathrm{P}\right)$ from PhytoFos 4-28-10 (4N-12.2P-8.3K), and metalaxyl on growth and foliar $\mathrm{PO}_{4}-\mathrm{P}$ concentrations of chinese hibiscus, shooting star, downy jasmine, spathiphyllums, and areca palm.

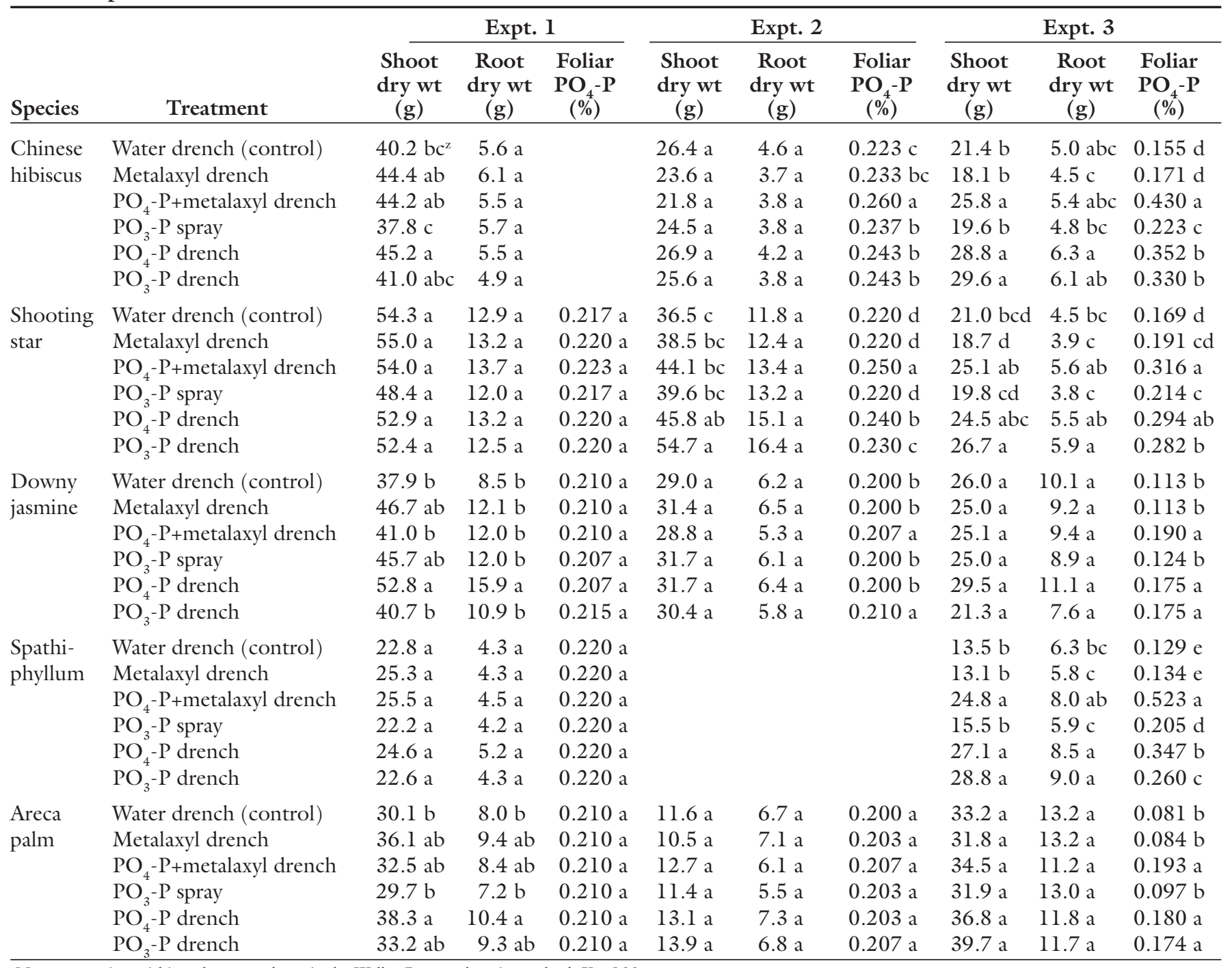

${ }^{2}$ Mean separation within columns and species by Waller-Duncan k-ratio method, $\mathrm{K}=100$.

${ }^{\mathrm{y}} 1 \mathrm{~g}=0.0353 \mathrm{oz}$.

other than from treatments was used (Expt. 3), plants receiving drenches of $\mathrm{PO}_{4}-\mathrm{P}$, PhytoFos 4-28-10, or $\mathrm{PO}_{4}$ $\mathrm{P}+$ metalaxyl had higher leaf concentrations of $\mathrm{PO}_{4}-\mathrm{P}$ than those receiving other treatments.

\section{Discussion}

Since the shoot and root dry weights were not significantly different between the metalaxyl only treatments and the water controls in all three experiments and all five species, even minor root rot diseases due to Pythium or Phytophthora can be ruled out as a significant factor in this study. Therefore, any significant growth responses observed in PhytoFos 4-28-10 -treated plants should be due to fertility effects, rather than disease suppression by this product. That the $\mathrm{PO}_{3}-\mathrm{P}$ product used (PhytoFos 4-28-10) also contains $\mathrm{N}$ and $\mathrm{K}$ means that some of the growth responses observed from this product could be due to the $\mathrm{N}$ and/or K. However, the fact that PhytoFos 4-28-10-treated plants never had shoot or root dry weights or foliar $\mathrm{PO}_{4}-\mathrm{P}$ concentrations greater than plants treated with $\mathrm{PO}_{4}-\mathrm{P}$ alone, suggests that growth responses observed probably were not due to the $\mathrm{N}$ or $\mathrm{K}$ in PhytoFos 4-28-10. Also, if the $\mathrm{N}$ in the PhytoFos 4-28-10 treatments had resulted in an increase in growth without concomitant increases in $\mathrm{P}$ uptake, leaf $\mathrm{PO}_{4}-\mathrm{P}$ concentrations would be expected to decrease due to dilution relative to the equivalent $\mathrm{PO}_{4}-\mathrm{P}$ treatments, a phenomenon observed only for spathiphyllum in Expt. 3 .

One consistent response for all plant species, monocots and dicots, that is not understood is the apparent synergistic effect of metalaxyl and $\mathrm{PO}_{4}$ $P$ in a soil drench. With the exception of shoot dry weights of shooting star in Expt. 2 and of downy jasmine in Expt. 1 , both growth parameters, as well as foliar $\mathrm{PO}_{4}-\mathrm{P}$ concentrations were as great or greater for this combination of treatments than for any other treatment across all five species. The PhytoFos 4-28-10 drenches should provide equivalent levels of $\mathrm{P}$ and disease control as the $\mathrm{PO}_{4}-\mathrm{P}+$ metalaxyl drenches if the $\mathrm{P}$ in $\mathrm{PO}_{3}-\mathrm{P}$ is as readily 
usable as it is in $\mathrm{PO}_{4}-\mathrm{P}$. When grown with or without supplemental $P$, the plants receiving the PhytoFos 4-28-10 drenches generally had shoot and root dry weights equivalent to those receiving the $\mathrm{PO}_{4}-\mathrm{P}+$ metalaxyl drenches. However, when no other $\mathrm{P}$ source was provided, foliar $\mathrm{PO}_{4}-\mathrm{P}$ concentrations were lower for PhytoFos 4-28-10drenched plants of hibiscus, shooting star, and spathiphyllum than for $\mathrm{PO}_{4}^{-}$ $\mathrm{P}+$ metalaxyl-drenched plants, suggesting that $\mathrm{P}$ was not limiting growth in the PhytoFos 4-28-10-drenched plants, but that $\mathrm{P}$ from $\mathrm{PO}_{3}-\mathrm{P}$ was not as readily usable as from $\mathrm{PO}_{4}-\mathrm{P}$.

Results of these experiments showed consistent trends, even among diverse plant taxa. When Osmocote Plus 15-9-2 fertilizer was used on all treatments, growth responses to additional $\mathrm{P}$ from foliar- or soil-applied PhytoFos 4-28-10 or $\mathrm{PO}_{4}-\mathrm{P}$ were minimal. This suggests that supplemental $\mathrm{P}$ was generally not beneficial from a plant nutrition perspective. When no other P source than the treatments were used (Expt. 3), however, three of the five species showed greater growth when treated with PhytoFos 4-28-10, $\mathrm{PO}_{4}-\mathrm{P}$, or $\mathrm{PO}_{4}-\mathrm{P}+$ Metalaxyl as soil drenches than with other treatments. These data suggest that when applied as a soil drench at equivalent $\mathrm{P}$ rates, PhytoFos 4-28-10 and $\mathrm{PO}_{4}^{-}$ $\mathrm{P}$ generally produced similar quality plants. Foliar sprays with PhytoFos 4-28-10 at its recommended rate did not improve plant growth in any species above that of the no P controls. The amount of $\mathrm{P}$ supplied by the foliar application of PhytoFos 4-28-10 may have been insufficient for plant demands. Alternatively, the $\mathrm{PO}_{3}-\mathrm{P}$ absorbed through the foliage may not be in a usable form (Guest and Grant, 1991), whereas $\mathrm{PO}_{3}-\mathrm{P}$ applied to the soil could have been oxidized to $\mathrm{PO}_{4}{ }^{-}$ $\mathrm{P}$ and taken up in that form by plants (Adams and Conrad, 1953; Malacinski and Konetzka, 1966).

Foliar $\mathrm{PO}_{4}-\mathrm{P}$ concentrations from plants sprayed with PhytoFos 4-28-10 were equal to or slightly greater than those of plants receiving no $\mathrm{P}$ (Expt. 3) or supplemental $\mathrm{P}$ (Expt. 2), indicating that a very small amount of $\mathrm{PO}_{3}-\mathrm{P}$ applied to foliage was incorporated into the plant tissue as $\mathrm{PO}_{4}-\mathrm{P}$. $\mathrm{PO}_{3}-\mathrm{P}$ is believed to be oxidized to $\mathrm{PO}_{4}^{-}-\mathrm{P}$ within plant tissue (Bezuidenhout et al., 1987).

In conclusion, it appears that PhytoFos 4-28-10 applied to the soil was about as effective as an equivalent amount of $\mathrm{PO}_{4}-\mathrm{P}$. However, due to the higher cost of $\mathrm{PO}_{3}-\mathrm{P}$ relative to $\mathrm{PO}_{4}-\mathrm{P}$, its use solely as a $\mathrm{P}$ source may not be economically justified. The uptake of $\mathrm{P}$ and growth response due to foliar-applied $\mathrm{PO}_{3}-\mathrm{P}$ were minimal, suggesting that plant growth and yield responses in other studies using foliarapplied $\mathrm{PO}_{3}-\mathrm{P}$ may be due more to the fungicidal properties of this material than as a P source.

\section{Literature cited}

Adams, F. and J.P. Conrad. 1953. Transition of phosphite to phosphate in soils. Soil Sci. 75:361-371.

Bezuidenhout, J.J., J.M. Darvas, and J.M. Kotze. 1987. The dynamics and distribution of phosphate in avocado trees treated with phosetyl-Al. South African Avocado Growers Assn. Yrbk. 10:101-103.

Guest, D. and B. Grant. 1991. The complex action of phosphonates as anti-fungal agent. Biol. Rev. 66:159-187.

Hach, C.C., B.K. Bowden, A.B. Koplov, and S.V. Brayton, 1987. More powerful peroxide Kjeldahl digestion method. J. Assn. Offic. Anal. Chem. 70:783-787.

Kuo, S. 1996. Phosphorus. p. 869-919. In: J.M. Bartels (ed.). Methods of soil analysis. Part 3. Chemical methods. Soil Sci. Soc. Amer., Madison, Wis.

MacIntire, W.H., S.H. Winterberg, L.J. Hardin, A.J. Sterges, and L.B. Clements. 1950. Fertilizer evaluation of certain phosphorus, phosphorous, and phosphoric materials by means of pot cultures. Agron. J. 42:543-549.

Malacinski, G. and W.A. Konetzka. 1966. Bacterial oxidation of orthophosphite. J. Bacteriol. 91:578-582.

McDonald, A.E., B.R. Grant, and W.C. Plaxton. 2001. Phosphite (phosphorous acid): Its relevance in the environment and agriculture and influence on plant phosphate starvation response. J. Plant Nutr. 24:1505-1519.

Mengel, K. and E.A. Kirkby. 1979. Principles of plant nutrition. Intl. Potash Inst., Berne, Switzerland.

Rickard, D.A. 2000. A review of phosphorous acid and its salts as fertilizer materials. J. Plant Nutr. 23:161-180. 